\title{
Extensive Green Roofs (Modulars, Continuous and Aerial) Supported on Premolded Concrete Bases
}

\author{
Tatyane Nadja Martins de Mendonça, Vitor Muniz Henriques, and Aluísio Braz de Melo
}

\begin{abstract}
This study proposes extensive green roofs, based on three typologies, that in function of the resulting configuration are identified as modular, continuous and aerial. They all use herbaceous vegetation with premolded structures of light concrete, fabricated with a type of residue from the shoemaking industry, the Ethylene Vinyl Acetate (EVA). The typologies were designed and simulated, in real scale, in a laboratory, using medicinal plants. The modular typology uses vegetated blocks and corresponds to the simplest technique regarding installation and maintenance; the continuous typology is the system with vegetation and soil over plaques, providing the best plant development; the aerial type consists in the combination of vegetated blocks in two narrow bands of slab, with a screen between them, allowing the development of climbing plants, being this system the less biodiverse. All systems cater to the maximum weight parameter for extensive green roofs, and cater to the finalities expected from a green roof, with the possibility of having even additional contributions regarding thermal comfort, due to the use of a light aggregate in the composition of the premolded structures.
\end{abstract}

Index Terms-Eva residues, green roofs, herbaceous vegetation, premolded structures.

\section{INTRODUCTION}

A more sustainable construction aggregates more value to it, besides diminishing its impacts, improving life quality without compromising the future [1]. This brings us back to the need of searching for sustainable technologies in edifications and, by consequence, of the urban space, bringing benefits related to the quality of life of urban populations, contributing to a harmony between urban concrete and elements of nature. However, the materials commonly used by the construction industry in the western world, in general, generate thermal discomfort, transforming users in big energy consumers for cooling or heating. The sum of living units with these materials, allied to paving and asphalt have been creating a new ecosystem, characterized by heat islands and floods. Besides, several times the city air contains high levels of pollutants that are harmful to human health [2], due to industrial activities in the cities and the intensive use of motor vehicles.

Researchers have been pointing vegetation coverage as an attenuating solution for some of these problems in urban centers. Reference [3], for example, quantified the pollution

Manuscript received May 30, 2014; revised July 31, 2014. This work was supported in part by the Brazilian Government, under the CAPES scholarship for grad students. Extensive Green Roofs (Modulars, Continuous And Aerial) Supported on Premolded Concrete Bases and Eva Residues.

The authors are with the Universidade Federal da Paraíba, João Pessoa, PB (58051-900) Brazil (e-mail: tatyanemartinn@gmail.com, tatyanemartinn@gmail.com, tatyanemartinn@gmail.com). removed by some green roofs in Chicago, U.S.A., in a work that presents the quantification of the polluting compounds present in the atmosphere treated by this system.

In Germany, the concept of green roof is already vastly spread, besides, this country was the precursor in the development of the modern green roofs. Many other countries in Europe are investing in this proposition [4]. In 2009, the city of Toronto, Canada, adopted a norm demanding and regulating the construction of green roofs in new residential, commercial and institutional edifications [5].

In the city of Chicago, U.S.A., since 2001 the initiative on the city hall's roof opened a precedent for the application on other edifications [6]. The cities of Philadelphia and Atlanta, U.S.A., already have incentive programs in course [7]. Other North American cities, as New York, Los Angeles, San Francisco, Portland and Washington D.C. have been searching for programs related to green roofs [8], [9].

In Brazil there are already companies in the field, concentrated mainly in the south and southeast regions of the country [10], besides laws and bills in course. In the city of São Paulo, for example, in 2009 was approved a bill - number $115 / 09$ - referring to the installation of green roofs in that capital [11]. In Goiânia, in 2012, was instituted the Programa Telhado Verde (Green Roof Program) [12]; In the state of Espírito Santo was presented to the Legislative Assembly the Bill number 260/2012, which defends the creation of green roofs in urban spaces [13]. In Rio Grande do Sul there are shopping malls, hospitals and many other commercial establishments and residencies with this king of coverage [14]. The state of Santa Catarina already has a law that defines the creation of the Programa Estadual de Incentivo à Adoção de Telhados Verdes (State Program of Inducement for Adopting Green Roofs) [15], as there is in Rio de Janeiro [16].

In Curitiba there isn't a law yet, but there's property tax (IPTU) reduction for real estates with green areas, including green roofs [17]. In João Pessoa was disclosed, around 2013, a bill that would benefit green roof owners with property tax reductions [18]. However, there are no companies in this field in the state. By developing a more accessible technology for green roofs that could allow them to be produced in the region itself, it is expected that there will be a greater dissemination of this practice, among the options of technologically viable roofs.

Regarding the technology to execute green roofs, the International Green Roof Association (IGRA) classifies them into three types: extensive, semi-intensive and intensive. The extensive correspond to the ones that contain herbaceous vegetation, being the simplest kind of green roof, with low maintenance and low weight over the concrete slab, not more 
than $150\left(\mathrm{~kg} / \mathrm{m}^{2}\right)$, therefore, not requiring structural reinforcement in the edification. The semi-intensive are the intermediate ones, supporting bushes, commonly are made combinations of bushes and herbs, it is a system that doesn't go over $200\left(\mathrm{~kg} / \mathrm{m}^{2}\right)$, needs irrigation and periodic maintenance. The intensive correspond to the most complex ones, generating a load of up to $500\left(\mathrm{~kg} / \mathrm{m}^{2}\right)$, demanding the greater maintenance, as it holds trees and being able to be used as a garden park. This last kind of green roof will influence in the structural project of the edification, due to the heavy load of the system [19].

Besides this classification, ecologic covers can also be differentiated regarding the way they are applied, in a continuous, modular or aerial manner [20]. In the first, the system components, as draining, substrate retention, substrate and vegetation are continuously disposed in layers; in the modular system, the modules correspond to independent units that perform the functions of substrate retention and holding the vegetation, as well as draining, some possessing even an anti-root membrane. These units are disposed on the concrete slab, filling all of it, even giving a continuous effect, but different from the previous, it consists of a system of practical installation and maintenance, being versatile, allowing the garden to be easily reconfigured with the repositioning of the vegetated modules. At last, the roofs of the aerial type are created for climbing plants, where the substrate with the root system of the plant stays on one side, allowing the plant to ramify over the rest of the concrete slab. This system is the simplest to install, but it doesn't have some benefits of the previous ones as, for example, in relation to the capacity of retaining rain water.

Reference [21] studied rain water retention in modular systems applied in green roofs, proving its effectiveness, once that, with their installation, there's a retardation in rain water runoff, as it occurs in the continuous system. Part of the rain water is absorbed by the vegetation, part returns to the atmosphere through evapotranspiration and the other part is retained in the soil itself inside the vegetated module, contributing to reduce the volume of water to the public draining system. The accumulation of rain water retained by a certain area of green roofs might avoid floods, a serious problem faced by many large cities during times of intense rain in a short time. The fact is that, independently of the system, they all provide some kind of benefit to the edification, some more, some less. The larger the vegetated area and the size of the plants, more will be the pollutant, rain water and noise retention.

It is important to phrase that below the layers of the vegetated modules, waterproofing the concrete slab cannot be voided and, depending on the size of the plants adopted and their root systems, an anti-root barrier may be required.

Despite the benefits inherent to the installation of green roofs, a study brought up the discussion of how "green" are the green roofs [22], as the popular techniques use non-recycled polymers, besides, the work presents an estimative of how long should the green roof installed with these materials be active to compensate it environmentally. Because of this, one must really be critical when presenting the benefits of a green roof, once that in it might have been used materials that collaborate in damaging the environment, thus bringing more harm to the planet than urban improvements.

Facing these problems, studies have been conducted in the search for materials that certify the sustainability of this technology. Among these efforts, for example, there are companies that commercialize modular systems that use recycled Polyethylene terephthalate (PET) bottles. Additionally to this material, modules made with residues of Etileno-Vinil-Acetato (EVA) were commercialized by a Brazilian company, and several installations of green roofs were made using this technology, as for example at the Erich Heine School, in Rio de Janeiro [23]. Nowadays, the product is no longer commercialized and the justification given by the company was that the costs with the production and transportation were high.

These EVA residues (just what is left from cutting off the shoe soles) are generated in great volume in the shoemaking industries, being a potentially reusable material as a light aggregate in cement compounds. Indeed, many researches [24]-[28] have underlined the possibility of using this material in civil construction as a light aggregate in the elaboration of sealing blocks, with no structural function. Other studies have been evaluating the use of EVA aggregate in the making of cement plaques, for the application in systems of floating floors in multifamily vertical residential edifications, aiming to attenuate the noise impact between floors [29]-[31].

The EVA residue can generate countless environmental problems, if the proper destination is not given to it. Being a thermo-fixed material, it has limitations to be reused. Although [32] have proposed chemical recycling for the residues in question, the reutilization processes still is important, as such residues continue to be a starting material in other productive cycles, without greater energy costs.

It seems to be interesting to search for solutions that seek to develop products to be used in edifications at a given region, reusing waste generated from the local industries. This way, the present study - in progress - proposes to develop green roofs supported on light concrete pre-molded elements, made with the aggregate of EVA residues substituting the natural aggregate. The proposal focuses on extensive green roofs, based on three typologies that, in function of the resulting configuration, are identified as modular, continuous and aerial. The study is being developed in a region considered popular for shoemaking, therefore, also a center of EVA residue production. Given the situation, using this residue as an aggregate combines two environmental gains: the first related to profiting from a material that would be discarded, at the same time that it saves natural resources in the making of the modules; the second, in relation to the development of a green roof technique using materials produced locally, not involving further costs to obtain and transport them. Add to this the possible contributions to the quality of the constructed environment, in its several scales (edification, neighborhood, city), as the prospect of improving thermal comfort, retention of pollutants, rain water, noise, etc., possible due to the use of green roofs on edifications. 


\section{Methodology}

The present extensive green roof proposal uses two geometries of pre-molded structures produced with light cementations composites, with EVA aggregate (90\%) and sand (10\%), both using the proportion 1:5 (Portland CP V ARI cement: aggregates; in volume). The first geometry, named TEVA block, was developed with the following dimensions, $35 \mathrm{~cm} \times 35 \mathrm{~cm} \times 13 \mathrm{~cm}$ (length, width and height), containing four compartments of $13 \mathrm{~cm} \times 13 \mathrm{~cm} \times 10$ $\mathrm{cm}$ (length, width and depth), destined to hold the substrate and vegetation (Fig. 1). Initially, the mold to produce the TEVA block was made with naval veneer covered with formica. The second geometry adopted was a plaque of dimensions $35 \mathrm{~cm} \times 35 \mathrm{~cm} \times 3.5 \mathrm{~cm}$ (length, width and height), named TEVA plaque, which corresponds to the same geometry developed by [29] in studies that proposed its use for floating floor systems. This plaque was also produced with a mold of naval veneer covered with paint. The moldings were performed over a vibrating table and soon after unmolding the elements, they were cured in a wet chamber, followed by an immersion in lime saturated water, up to seven days.

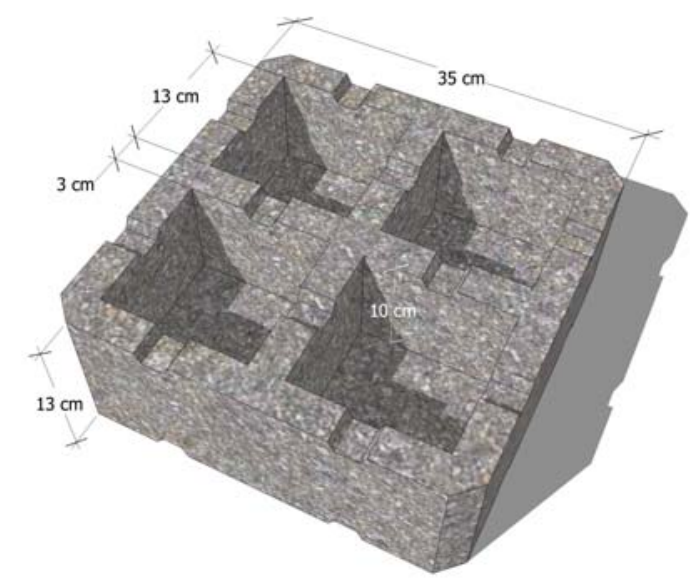

(a)

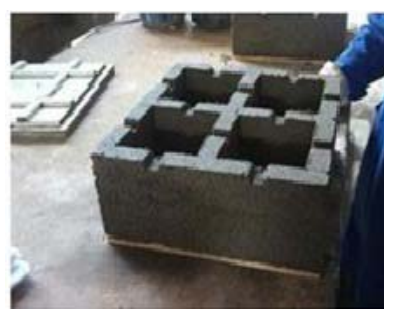

(b)

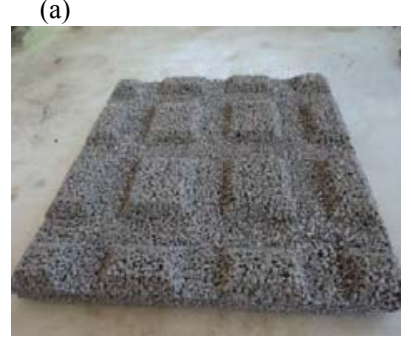

(c)
Fig. 1. TEVA block in drawing (a) and after manufacturing (b); TEVA plaque inverted with low prominences (c).

Both premolded structures proposed are self-draining, an important characteristic (draining the excess substrate water), because at the same time that it retains the substrate, avoids the accumulation of liquid and possible rotting of roots. As the TEVA block, the TEVA plaque, seen in an inverted position in Fig. 1(c), possesses low prominences to make feasible for the water to runoff between the plaque and the concrete slab.

The setups for the different green roof compositions (modular, continuous and aerial) were drawn with the aid of SketchUp Software 8.0, and the simulations of the real scale systems were made in the laboratory. The plant species were selected and cultivated in the modules by the Centro de Biotecnologia (CBIOTEC - Biotechnology Center) of UFPB (Universidade Federal da Paraíba - Paraíba Federal University), Brazil.

The three proposed green roof systems - modular, continuous and aerial - are achieved through two types of premolded bases - the TEVA block and the TEVA plaque.

\section{RESULTS AND DisCUSSION}

In Fig. 2 can be seen the three proposed systems, considering the hypothetical segment of a slab, already waterproofed. The TEVA blocks can be arranged side by side, with the cavities facing up so that they can be vegetated; but by having the cavities facing down, the blocks work as a path to walk on during the maintenance visits (Fig. 2 - right segment). The aerial system is also configured using the modular block system, however its arrangement consists in disposing the TEVA blocks in two distanced stripes that will later be interconnected with a screen (Fig. 2 - segment to the left). In the continuous system, the TEVA plaques are disposed side by side, in a way that will form an uniform structure over the concrete slab, apt to receive substrate and vegetation Fig. 2.

As an extensive green roof, where herbaceous plant species develop, it is not necessary to concern about an anti-root barrier. Observe that in the three types of green roof the vegetation does not get in direct contact with the concrete slab, once that the modules themselves (blocks and plaques) at the same time as they receive a layer of substrate (soil), they also serve as a physical barrier for the root system, and are self-draining.

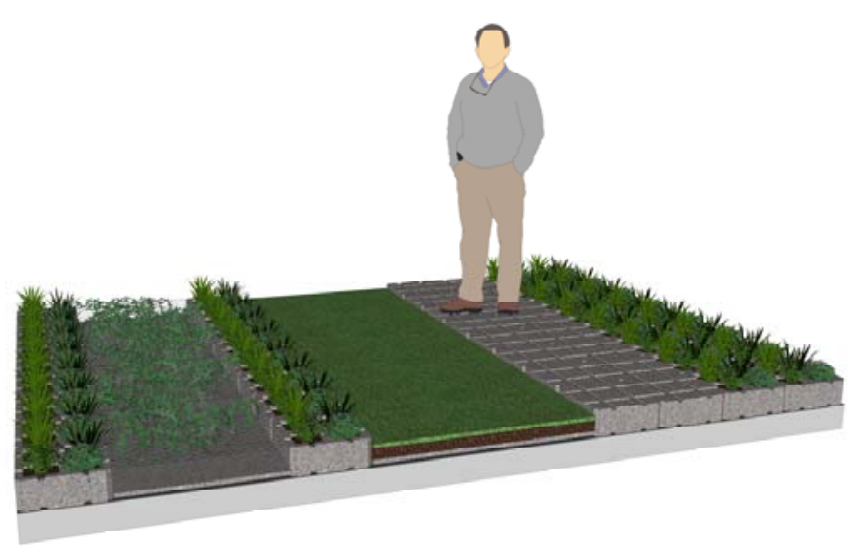

Fig. 2. Proposal of an arrangement for the three types of green roof using TEVA blocks and TEVA plaques. Angled front view with perpendicular cut.

In the aerial type, the screen must be connected with the stripes of TEVA blocks disposed on the sides, by a fixating system that guarantee a level of tension to the screen so it can adequately support the vegetation load, when it branches over the screen. In the initial tests, in real scale, done in the laboratory, there was still not enough time for the climbing plants put in the TEVA side blocks to grow over the screen (Fig. 3). However, we realized the need to set TEVA plaques under the screen to work as a filter, avoiding the dry leaves that might naturally fall over time and are carried by the rain to become a problem, clogging the drain system on the slab. 
Furthermore, the presence of TEVA plaques on the aerial green roof, as they are manufactured of a light aggregate with the reuse of EVA residue, it will certainly convey favorable thermal properties, which may also contribute to attenuate the heat from the roof itself. The vegetal that is starting to develop towards the screen is the Milona (Cissampelos sympodialis), a climbing plant used for medicinal purposes. It must also be noticed that, in this system, after the vegetation ramifies, the access to the area under the screen will be more difficult.
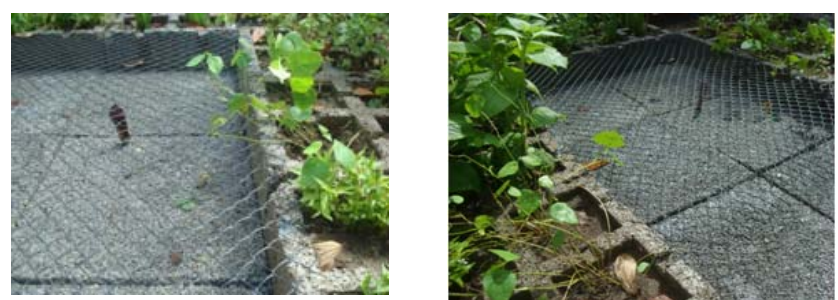

Fig. 3. Aerial green roof with TEVA plaques under the screen.

The green roof with of a continuous system (segment II in Fig. 2), showcased in Fig. 4, because it is adjacent to the modular system with TEVA blocks, will be limited regarding the depth of the substrate with vegetation, due to the total height of the TEVA blocks - corresponding to $10 \mathrm{~cm}$ in this case. However, if the continuous system is used on its own, it might receive a greater amount of substrate, increasing its depth to the development of root systems, respecting the limitations of using herbaceous vegetation. In this case, the limits to the substrate level over the TEVA plaques will be the platband of the edification, or yet be delimited with the construction of a small wall around the edges of the area to be vegetated.

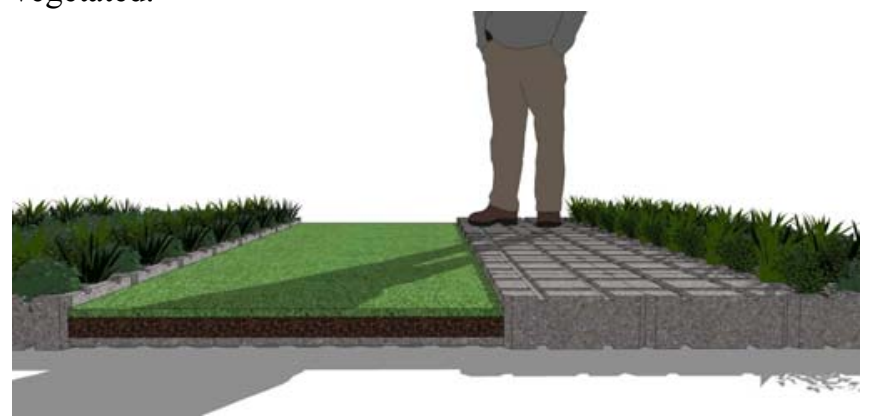

Fig. 4. Image of the transition between the continuous and the modular green roof systems.
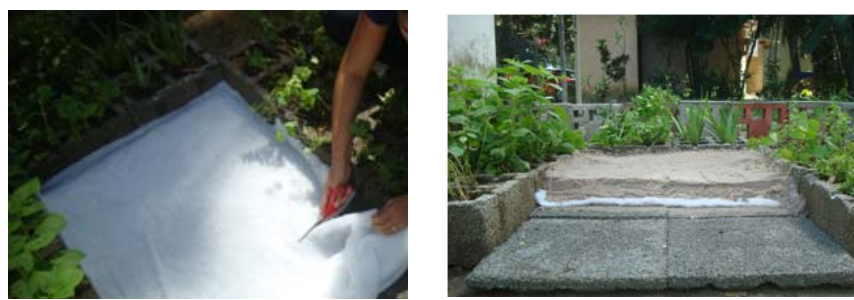

Fig. 5. Image showing the placement of a polyester batting and sand over the TEVA plaques.

Another important observation is that due to TEVA plaques not having a connector between them, the simple side by side disposition end up living open spaces (seal failures), through which part of the substrate might possibly be lost over time. To prevent this phenomenon, we adopted the procedure presented by [10], which is putting a layer of polyester batting over the TEVA plaques to work as a substrate retention membrane. In Fig. 5, it is possible to visualize the simulation of applying a polyester batting and substrate over TEVA plaques.

In the simulation of the continuous green roof, presented in Fig. 5, we used fine sand over the retention batting (in white), as to represent the substrate, that is, not the adequate substrate, considering that it was simply a test, not the definitive setting. It is relevant to point out the importance of the choice of the proper substrate for the development of the vegetation and to maintain the permeability of the system. Clay soils will tend to compact more, raising difficulties with the soil aeration, compromising its permeability; whereas sand soils are poor in nutrients and have a low capacity to retain humidity.

Normally, in the green roof with a continuous system, there is more liberty to occur, in the substrate, the lateral development of roots and microfauna, which may make possible to house worms, an important organism to the good maintenance of the soil. The main advantage of this system is with relation to the low impact of its weight over the concrete slab in comparison with the modular system, and it also allows the development of a vegetal diversity, once that there are no boundaries between the plaques Fig. 7.

At last, the modular system corresponds to the simplest one, with relation to installation and maintenance. The proposed TEVA blocks are vegetated and disposed side by side, as seen in segment III, Fig. 2, and, depending on the landscape project, the non-vegetated blocks can be placed inverted to be used as walking paths for appreciation or maintenance, as it can be seen in Fig. 4.

In the three green roof systems proposed, the plants to be developed can be ornamental, medicinal, leafy vegetables, among other herbaceous. For this study we cultivated medicinal vegetal species donated by the CBIOTEC. Among them, there are the country borage (Plectranthus amboinicus (Lour.) Spr), the peppermint (Mentha piperita L.), Masha-hari (Justicia pectoralis Jacq), 'milona' (Cissampelos sympodialis) and chamomile (Matricaria recutita L. ), as seen in Fig. 6.

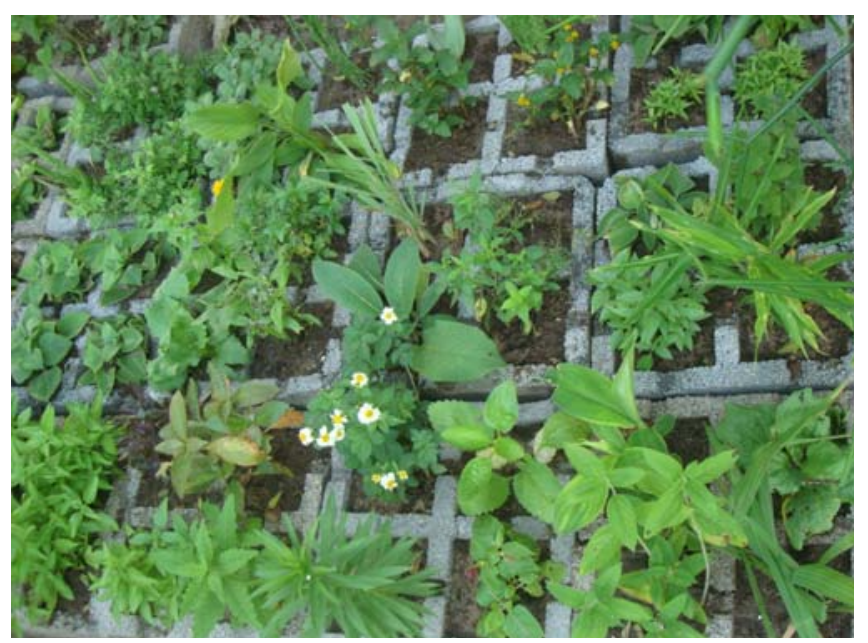

Fig. 6. Variety of medicinal plants cultivated during the testing of TEVA blocks with vegetation.

The dimensions of the TEVA block and TEVA plaque, as well as their respective masses, can be found summarized in 
Fig. 7, including an estimate by meters squared of the mass of the green roof systems proposed.

The aerial system, for having a configuration that predicts the use of TEVA blocks aligned in distances stripes, connected only by screens, it is difficult to estimate the weight by $\mathrm{m}^{2}$, once that the distance limit between the modules will depend on the capacity of the climbing vegetal to branch over. Therefore, it depends on the distance limit for the plant to develop away from its nutritional source, the TEVA blocks with soil.

However, considering the data presented in Fig. 7, adding the mass of the substrate and vegetation, it is estimated that none of the proposed systems will go over the maximum limit of acceptable load for extensive green roofs, which is of 150 $\mathrm{kg} / \mathrm{m}^{2}$. Among the three proposed systems of green roofs, the modular might get close to this limit.

Actually, based on the results obtained so far, we cannot predict yet how the plants chosen will behave in each system with time. The hypothesis is that the continuous system might have a better performance, once having no barriers between the plaques may allow the plants to have a greater area and volume of substrate for lateral fixation, important factor for plants that are more exposed to wind, as it happens on a roof. Besides, the substrate might suffer less compaction due to the paths opened by the root systems.

On the other hand, we have to point out the versatility of the modular system, once that, being modules, they have easy maintenance and allow the reconfiguration of the garden outline in a more practical way. That is, new shapes can be easily obtained, with the use of some stripes of TEVA blocks as walking paths among the vegetated TEVA blocks, what can change over time depending on the need. Moreover, new combinations with different module geometries (TEVA blocks and TEVA plaques) can be made, in a way that walkable areas are created alongside with the continuous system. In this case, the ideal is to guarantee the modular coordination, maintaining the dimensions width and length equal for geometries, TEVA plaques and TEVA blocks, in order to best obtain a perfect fitting.
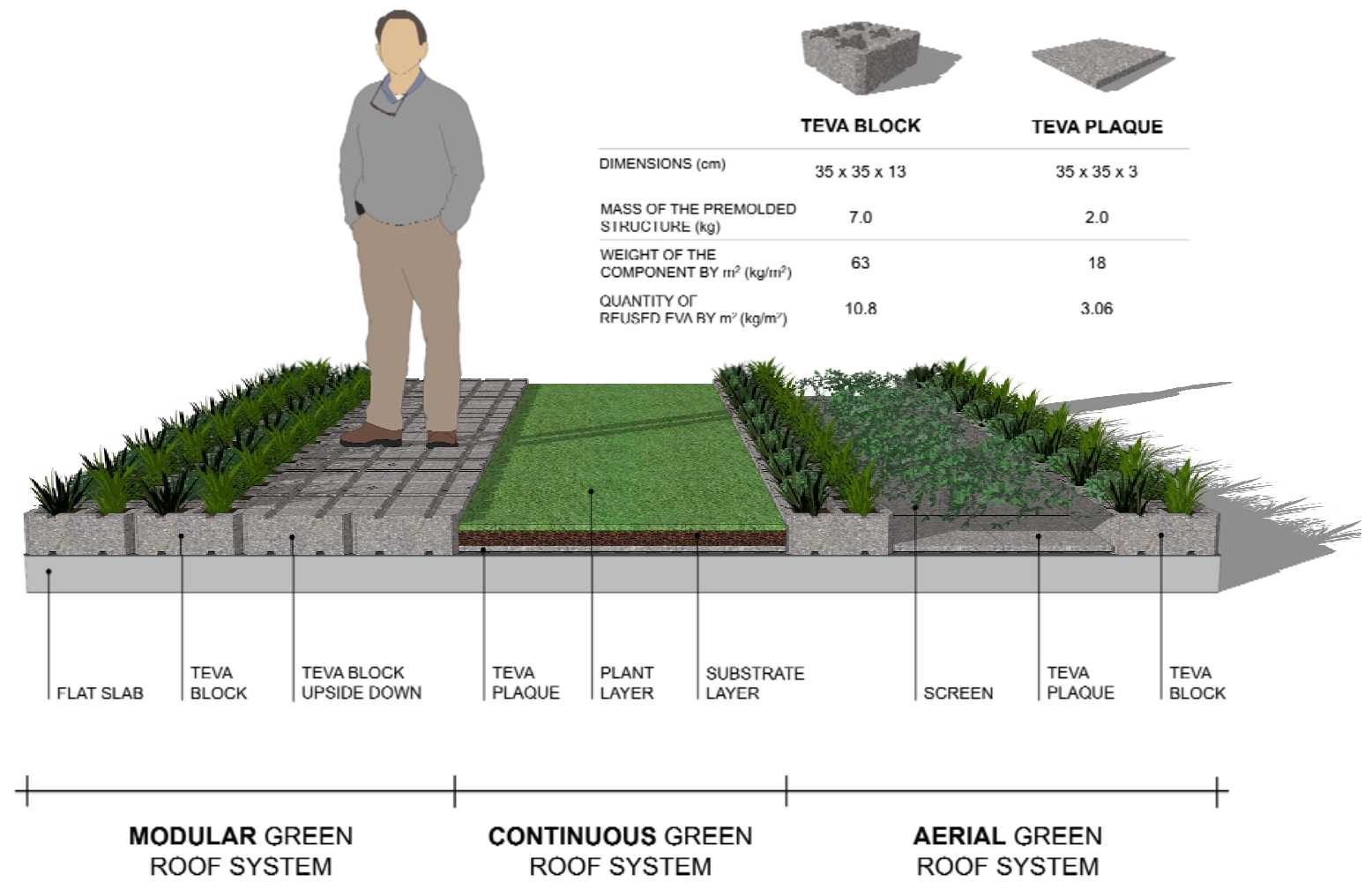

\begin{tabular}{|c|c|c|c|}
\hline $\begin{array}{l}\text { PLANTATION AND } \\
\text { INSTALLATION }\end{array}$ & $\begin{array}{l}\text { INSTALLATION OF BLOCKS } \\
\text { ALREADY PLANTED }\end{array}$ & $\begin{array}{l}\text { PLANTATION AFTER INSTALATTION } \\
\text { OF PREMOLDED STRUCTURE }\end{array}$ & $\begin{array}{l}\text { PLANTATION AFTER INSTALLATION } \\
\text { OF PREMOLDED STRUCTURE }\end{array}$ \\
\hline \multirow[t]{2}{*}{ ADVANTAGES } & $\begin{array}{l}\text { INDEPENDENT SYSTEM: } \\
\text { MOBILITY AND PRACTICALITY }\end{array}$ & $\begin{array}{l}\text { DEVELOPMENT OF } \\
\text { VEGETAL DIVERSITY }\end{array}$ & \multirow{2}{*}{ LOW WEIGHT } \\
\hline & $\begin{array}{l}\text { BLOCKS COULD BE INSTALLED } \\
\text { ALREADY PLANTED }\end{array}$ & $\begin{array}{l}\text { LATERAL DEVELOPMENT OF } \\
\text { ROOTS AND MICROFAUNA }\end{array}$ & \\
\hline DISAVANTAGES & HIGH WEIGHT & $\begin{array}{l}\text { NEED FOR A SUBSTRATE } \\
\text { RETENTION MEMBRANE }\end{array}$ & $\begin{array}{l}\text { NEED EXTRA COMPONENTS } \\
\text { POOR IN VEGETAL DIVERSITY }\end{array}$ \\
\hline MAINTENANCE & $\begin{array}{l}\text { EASY REPLACEMENT } \\
\text { OF BLOCKS }\end{array}$ & $\begin{array}{l}\text { HARD: NEED TO REMOVE THE LAYERS OF } \\
\text { SOIL AND VEGETATION AND REPLANT IT }\end{array}$ & $\begin{array}{l}\text { CLOSED SYSTEM: HARD TO SEPARATE } \\
\text { PARTS FROM EACH OTHER BUT POSSIBLEE }\end{array}$ \\
\hline
\end{tabular}

Fig. 7. Comparison between the types of green roof and their structural components.

Finally, besides the contributions expected from a vegetated coverage installed on an edification, such as thermal comfort improvement, diminishing superficial water runoff, slab protection, among others, we expect that the three proposed green roof systems (modular, continuous and aerial) also confirm their particular contributions due to the 
use of light cement compounds, fabricated with EVA residues. In this sense, it has to be highlighted that the EVA residue itself has thermal insulation properties, what will probably add to the improvements on thermal comfort by the green roofs developed with the premolded structures proposed, TEVA blocks and TEVA plaques. Moreover, considering the high water absorption $(>20 \%)$ by the premolded structures proposed, this might contribute with the water storage capacity of the system itself, what might aid in retaining the humidity longer, altering the periodic watering of the plants.

\section{CONCLUSIONS}

The present study, however a work in progress, allows us to identify the potentialities of the green roof systems proposed based on three typologies, identified as modular, continuous and aerial. The following aspects may be highlighted:

The modular system is the most practical in terms of installation and maintenance, as more flexible in allowing a further reconfiguration of the garden. According to estimates, it is also the costliest, due to the use of more material in the making of the modules, which also leaves the system up to three times heavier than the continuous type.

The continuous system is presented as the best technique with relation to plant development and littlest weight over square meter. Despite its advantages, one must remember that in this system it is necessary to use a batting for nutrient retention, an additional non-recyclable material.

The aerial system is the lightest of the systems and the less biodiverse, once that there cannot be made many climbing plant combinations, also being the most difficult system to perform eventual maintenances. The screens and hooks (to hold the screen to the module) are additional materials, and indispensible to the system.

\section{ACKNOWLEDGMENTS}

To the laboratory where the study is being held, for the material and technical support in executing the work; to the Centro de Biotecnologia (CBIOTEC) of the Brazilian university for providing the vegetable seedlings; to agronomist Fernando Viana (UFPB) that have been contributing with the Botanic related aspects; and to Samara T. A. de Medeiros for translating this paper.

\section{REFERENCES}

[1] G. Silva, "Sustainability assessment of buildings and Brazilian offices: guidelines and methodological basis," Ph.D. dissertation, Dept. Engineering, São Paulo Univ., São Paulo, Brazil, 2003.

[2] H. Mayer, "Air pollution in cities," Atmospheric environment, vol. 33, pp. 4029-4037, 1999.

[3] J. Yang, Q. Yu, and P. Gong, "Quantifying air pollution removal by green roofs in Chicago," Atmospheric environment, vol. 42, pp. 7266-7273, 2008

[4] S. R. Araújo, "The functions of green roofs in urban areas in the management and planning of water resources," Monograph, Institute of Forestry of the Federal Rural Rio de Janeiro Univ., Rio de Janeiro, 2007.

[5] Toronto Green Roof Bylaw. (2014). [Online]. Available: http://www.toronto.ca/greenroofs/.
[6] City Hall's Rooftop Garden. (2014). [Online]. Available: http://www.cityofchicago.org/city/en/depts/dgs/supp_info/city_hall_ green roof.html

[7] U. S. Energy, Green Roof Improvement Fund. [Online]. Available: https://www.energycodes.gov/resource-center/policy/green-roof-imp rovement-fund-chicago-il.

[8] R. Cruger. Green Roofs Growing in US. [Online]. Available: http://www.treehugger.com/sustainable-product-design/green-roofsgrowing-in-us.html

[9] Industry Support. (2013). [Online]. Available: http://www.greenroofs.com/greenroofs 101/industry_support.htm

[10] A. C. Savi, "Green Roofs: comparative cost analysis with traditional roofing systems," Monograph, Federal Technological of Paraná Univ., Curitiba, 2012.

[11] O Estadão. Project 2009 is Stopped. [Online]. Available http://www.estadao.com.br/noticias/impresso,projeto-de-2009-esta-p arado,916116,0.htm.

[12] J. Opção. Hall Pass Bill Green Wants Property Tax. [Online]. Available

http://www.jornalopcao.com.br/posts/ultimas-noticias/prefeitura-que r-aprovar-projeto-de-iptu-verde.

[13] Projeto Bill Defends Use of Green Roof in Urban Areas. [Online]. Available

http://jusclip.com.br/projeto-de-lei-defende-uso-de-telhado-verde-em -areas-urbanas/

[14] E. J. Diehl, "Living roofs," Mini Course, Toni Backes Landscaping and Architecture, Hardman Hotel, Joao Pessoa, 2012.

[15] Lei Em Santa Catarina. [Online]. Available: http://www.ecotelhado.com.br/informacoesinterna/lei\%20em\%20san ta\%20catarina.pdf

[16] Lei $6349 / 12 \mid$ Lei $n^{\circ} 6.349$, de 30 de. [Online]. Available http://www.jusbrasil.com.br/legislacao/1033548/lei-6349-12-rio-de-j aneiro-rj.

[17] A. D. D. Fonte. Commission Approves Project that Requires Green Roof in Curitiba. [Online]. Available: http://revistasustentabilidade.com.br/direto-da-fonte-comissao-aprov a-projeto-que-obriga-telhado-verde-em-curitiba/

[18] Bill Provides for a Reduction of up to $50 \%$ of Property Tax to Citizens Who Promote Sustainable Attitudes. [Online]. Available: http://www.pbagora.com.br/conteudo.php?id=20130605122502\&cat =politica\&keys=projeto-preve-reducao-ate-iptu-cidadao-promover-at itudes-sustentaveis.

[19] Green Roof Types. [Online]. Available: http://www.igra-world.com/

[20] M. F. Ferreira. Green Roof: the Use of Cover Crops in Buildings. Available: [Online]. http://www.puc-rio.br/ensinopesq/ccpg/pibic/relatorio_resumo2007/r elatorios/art/art_manoela_de_freitas_ferreira.pdf

[21] E. S. Prowell, "An analysis of stormwater retention and detention of modular green roof blocks," M.S. thesis, Georgia Univ., Athens, Georgia, 2006.

[22] F. Bianchini and K. Hewage, "How "green" are the green roofs? Lifecycle analysis of green roof materials," Building and environment, vol. 48, pp. 57-65, 2012.

[23] N. C. Silva, "Green roof: construction system for greater efficiency and lower environmental impact," Monograph, Dept. Materials Engineering and Construction, Federal of Minas Gerais Univ., Minas Gerais, 2011.

[24] G. Garlet, "Utilization of waste EVA (Ethylene Vinyl Acetate) as aggregate for lightweight concrete in construction," M.S. Thesis, Federal of Rio Grande do Sul Univ., Porto Alegre, 1998.

[25] A. J. V. Bezerra, "Using waste of EVA footwear industry as lightweight aggregate in the production of hollow concrete block masonry with no structural function," M.S. thesis, Federal of Paraíba Univ., Campina Grande, 2002.

[26] R. S. Polari Filho, "Contribution to the recycling of waste from footwear industry in the construction process: an alternative to EVA block of masonry buildings," M.S. thesis, Graduate Program in Urban Engineering, Federal of Paraíba Univ., João Pessoa, 2005.

[27] F. M. D. Rocha, "Utilization of industrial wastes into alternative materials in view of dry construction: EVA pack - and streamlining of interlocking masonry," M.S. thesis, Graduate Program in Urban Engineering, Federal of Paraíba Univ., João Pessoa, 2008.

[28] A. B. Melo and M. R. F. L. Filho, "Evaluation of structural performance of prototype with walls constructed with EVA blocks," Built environment, vol. 9, pp. 141-155, Oct. 2009.

[29] F. A. Santos, "Evaluation of cement slabs with waste EVA as to their level of acoustic insulation of floating floors systems," M.S. thesis. 
Dept. Architecture and Urban Planning, Federal of Paraíba Univ., João Pessoa, 2013.

[30] S. P. Hax, "Study of the potential waste of EVA. On the impact noise insulation in buildings," M.S. thesis, Federal of Santa Maria Univ., 2002.

[31] L. C. Leal, L. Marquetto, M. F. O, Nunes, and B. F. Tutikan, "Lightweight concrete with eva recycled aggregate for impact noise attenuation," Materiales de construcción, vol. 63, pp. 309-316, 2013

[32] S. M. D. Prestes, "Reuse of waste EVA crosslinked by chemical recycling," Ph.D. dissertation, Dept. Science and Technology of Materials, Estadual Paulista Julio of Mesquita Filho Univ., Sorocaba, 2013.

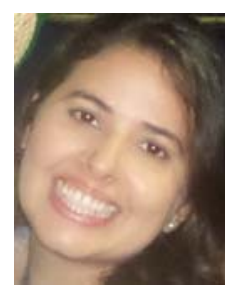

Tatyane Nadja Martins de Mendonça was born in João Pessoa, Paraíba, Brazil, in 1985. She graduated in bachelor and licentiate at the Universidade Federal da Paraíba (UFPB), João Pessoa, Paraíba, Brazil, in 2011. Since 2013 she has been in the programa de Pós Graduação em Engenharia Civil e Ambiental (PPGECAM), João Pessoa, Paraíba, Brazil, obtaining a Masters degree.

Besides being a graduate student, she teaches science at Centro Educacional Cenecista (CNEC) in João Pessoa, Paraíba, Brazil. She has experience in educational projects, entomology, reuse of materials and green roofs.

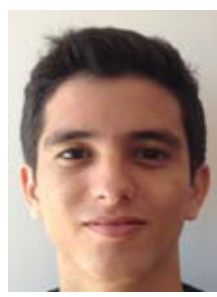

Vitor Muniz Henriques was born in João Pessoa Paraíba, Brazil, in 1994. He's an undergrad student at the Universidade Federal da Paraíba (UFPB), in Architecture and Urbanism, since 2012. He works in the area of Urbanism, with social behavior at public spaces, at the University's laboratory LECCUR (Laboratório de Estudos sobre Cidades, Culturas Contemporâneas e Urbanidades), since 2013; and he's also a member of the Office Model of Architecture and
Urbanism, TRAMA, an associate group of the University, which purpose is to affirm a commitment to the social reality of the community where the University is inserted and to work with non-solicited architecture.

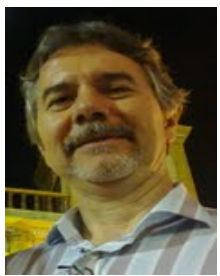

Aluísio Braz de Melo was born in Campina Grande, Paraíba, Brazil, in 1961. He graduated in architecture from the Universidade Federal da Paraíba (UFPB), João Pessoa, Paraíba, Brazil, in 1983 and he received his MA in architecture from the Escola de Engenharia de São Carlos / USP, São Carlos, São Paulo, Brasil, in 1996, he received his Ph.D. in science and engineering units IFSC, IQSC and EESC of the Universidade de São Paulo (USP), São Paulo, Brazil, in 2000, and he received hipost-doctoral at the Laboratório Nacional de Engenharia Civil (LNEC), in Lisbon, Portugal, in 2008-2009.

$\mathrm{He}$ is currently an associate professor at UFPB, in the Department of Architecture, accredited in the post-graduate architecture and urban planning and the post-graduate in civil and environmental engineering programs. He has experience in architecture and civil engineering, with emphasis on unconventional materials, mainly in the following topics: precast concrete, waste management, construction and demolition, waste recycling shoe industry artifacts in Portland cement. 